ESTANTE

DE LIVROS

\title{
A TERAPIA FAMILIAR MULTIGERACIONAL. INSTRUMENTOS E RECURSOS DO TERAPEUTA
}

Por Maurizio Andolfi (2018)

JULIANA SEGER SANVICENTE

Psicóloga consultora do Consulado Geral do Brasil em

Roma. o volume A Terapia Familiar Multigeracional - Instrumentos e Recursos do Terapeuta, Maurizio Andolfi sintetiza mais de quatro décadas de seu pensamento teórico com um texto de excepcional valor clínico. O livro, com primeira edição em 2015, na Itália, já traduzido, também, na França, na Espanha e nos Estados Unidos, teve sua primeira edição brasileira neste ano de 2018, tradução que tive o prazer de fazer. O lançamento do livro aconteceu com a presença do autor, no Rio de Janeiro, em agosto, durante o $13^{\circ}$ Congresso Brasileiro de Terapia Familiar, organizado pela ABRATEF.

Andolfi, psiquiatra infantil, diretor da prestigiosa Accademia di Psicoterapia della Famiglia, diretor da revista Terapia Familiare, é um pioneiro e um dos principais componentes da terapia sistêmico relacional no mundo. Trabalhou principalmente na Itália, nos Estados Unidos e na Austrália, país em que vive atualmente.

O texto possui uma estrutura sucinta e eficaz. Os assuntos que compõem os nove capítulos do livro expressam uma teoria reconhecida na prática. O primeiro e o segundo capítulos se estendem em um percurso epistemológico-histórico, com amplo espaço dedicado aos autores que permanecem significativos, independentemente do paradigma de referência. Encontramos, portanto, "personagens" importantes e seus trabalhos podem nos enriquecer e estimular: dos puristas do sistema, como Bateson, Haley, Escola de Milão, aos condutores, como Ackerman, Bowem, Satir, Minuchin, Whitaker, Framo e assim por diante. Além dos autores ligados à tradição dos trabalhos com as famílias, Andolfi disserta a partir da abertura do intrapsíquico para o relacional (Searles); da crença otimista, da matriz neofreudiana, dentre cujos principais objetivos do tratamento está a remoção de obstáculos específicos que impedem o desenvolvimento relacional da família (Horney); até a crença de que o ambiente tem influência decisiva na doença, juntamente com a confiança no poder reparador das relações (Sullivan).

Os capítulos seguintes são dedicados às transformações sociais e às novas configurações familiares, às modalidades de observação da família, à avaliação do funcionamento familiar, à construção da história terapêutica, à linguagem do encontro terapêutico, à linguagem corporal, ao silêncio e ao contato físico.

Todos os capítulos têm, como um fio condutor, dois construtos fundamentais: a pessoa do terapeuta e a procura por recursos existentes onde houver (famílias de origem, sistema de amizade, contexto social). Outro aspecto fundamental de suas premissas teóricas consiste na construção de um sistema de tratamento que parte do terapeuta e da sua capacidade de estar com as famílias e seus componentes.

$\mathrm{Na}$ concepção Andolfiana, o processo terapêutico torna-se a construção de relacionamentos, uma busca por recursos e não por etiquetas, o resgate do so- 
frimento e da dor como influentes fatores causadores de mudança. Esta intuição é uma demonstração tangível da profunda sensibilidade de seu autor. E, de fato, embora certamente não seja uma autobiografia, percebe-se a sua coragem ao expressar o seu descontentamento e a sua posição clínica em antagonismo com o excesso de protocolos de eficácia e evidence based, especialmente valorizados neste período histórico. Portanto, a posição do autor, como terapeuta clínico, está distante do modelo médico e a sua compreensão dos fenômenos inclui uma relação não fragmentária com a família, com o indivíduo e com seu sistema sociocultural.

Tendo realizado minha inteira formação profissional na Accademia di Psicoterapia della Famiglia, tive a oportunidade de verificar diretamente a congruência entre as premissas teóricas de Andolfi e seu modo de estar com as famílias. Os alunos são incentivados a olhar para si mesmos e explorar um processo indutivo com base em sua experiência de lidar com as famílias. Andolfi transmite a força de um método que está enraizado na prática e na coerência entre a premissa e as ações - suas palavras escritas vão na essência do que é feito em terapia.

O método multigeracional de Andolfi nos leva a refletir sobre a complexidade de uma aprendizagem que deve ser vivida para ser assimilada e que não pode ser traduzida em mais uma técnica entre os instrumentos do psicoterapeuta. A família só poderá redescobrir o papel de protagonista, se o terapeuta for capaz de inserir seus instrumentos dentro de uma relação vital, em vez de usá-los como remédios a serem administrados.

É importante salientar que este livro propõe a autorreflexão pessoal e profissional, convidando o terapeuta a aderir a uma ética rigorosa a fim de ser capaz de conduzir com responsabilidade e respeito o seu delicado trabalho tão brilhantemente demonstrado por Andolfi nestas páginas.

\section{REFERÊNCIAS}

Andolfi, M. (2018). A terapia familiar multigeracional. Instrumentos e recursos do terapeuta. Belo Horizonte: Artesã Editora.

\section{JULIANA SEGER SANVICENTE}

É psicóloga pela Faculdade de Psicologia da Pontifícia Universidade Católica do Rio Grande do Sul (PUCRS); máster em Direito do Menor pela Universidade La Sapienza de Roma, Itália; psicoterapeuta sistêmico relacional, especializada pela Accademia di Psicoterapia della Famiglia de Roma; membro do comitê técnico da revista interdisciplinar de pesquisa e intervenção relacional "Terapia Familiare". Trabalha no âmbito clínico com casais e famílias, no campo das adoções internacionais e é psicóloga consultora do Consulado Geral do Brasil em Roma. E-mail:jusanvicente@yahoo.com 